\title{
MANUAIS ADMINISTRATIVOS: TEORIA X REALIDADE
}

\author{
Maria Angela Quilici de Medeiros*
}

MEDEIROS, M.A.Q de Manuais administrativos: teoria $x$ realidade. Nota previa. Rev. Esc. Enf. USP, São Paulo, 23(3):371-372, dez. 1989.

\section{NOTA PRÉVIA}

Segundo a Coordenadoria de Assistência Médica e Hospitalar $\left(\mathrm{CAMH}^{2}\right)$, Manual é uma coleção sistematizada de instrumentos normativos e atos de interesse de consulta de setores ou de ocupantes de cargos e funçöes, podendo ser mais ou menos detalhado de acordo com o fim a que se destina (Portaria MS no 16/73).

ANDRADE ${ }^{1}$, por sua vez, define Manual como sendo o recurso utilizado para reunir, de um modo organizado, o conjunto de normas e procedimentos técnico-administrativos estabelecidos para a execução das açōes de enfermagem, bem como informações significativas para o adequado, eficiente e eficaz desenvolvimento do trabalho da enfermagem. Constitui uma fonte de referência objetiva, clara e acessível ao pessoal de enfermagem sempre que necessário, favorecendo melhor interpretação das bases e linhas de orientação requeridas em termos de elaboração de planos de ação, execução, coordenação e controle, supervisão e avaliação das açōes de enfermagem.

Os Manuais Administrativos são instrumentos organizacionais cujos princípios básicos residem em dois modelos administrativos: na Administração Científica de Frederick Taylor e na Teoria Clássica de Henri Fayol. O primeiro modelo propōe a divisão do trabalho, buscando a eficiência da organização pela racionalização do trabalho do funcionário e pela soma das eficiências individuais de cada um deles; o segundo modelo concebe a estrutura organizacional como um todo, garantindo assim, a eficiência de todas as partes envolvidas: órgãos e pessoas ${ }^{3,4}$.

Este trabalho é composto por um levantamento bibliográfico sobre o tema e por uma sondagem de opiniōes, junto às enfermeiras de campo, quanto à percepção da influência de fatores externos à organização quando da utilização de Manuais Administrativos.

* Trabalho apresentado à disciplina Administraçāo de Serviços de Enfermagem I do Curso de Pós-Graduaçāo a nível de Mestrado da Escola de Enfermagem da Universidade de Săo Paulo.

** Enfermeira. Auxiliar de Ensino do Departamento de Orientaçāo Profissional da Escola de Enfermagem da Universidade de Săo Paulo. 
O objeto do presente estudo é analisar o Manual como instrumento administrativo no que se refere à padronização das açōes de enfermagem.

MEDEIROS, M.A.Q. de Administrative manuals: theory $\mathrm{x}$ reality. Preliminary note. Rev. Esc. Enf. USP, São Paulo, 23(3):371-372, Dec. 1989.

\section{PRELIMINARY NOTE}

The administrative manuals are organized methods, which basic principles are inserted in two administrative models: in the Scientific Administration by Frederick Taylor and in the Classical Theory by Henri Fayol. The first model proposes the division of the work searching for the efficiency of the organization by the coherence of the employee's work and by the addition of individual performances of each one of them; the second model conceives the organizational structure as itself, assuring the efficiency of all the parts involved: departments and people.

This work is settled by a bibliographical survey about the subject and by a research of opinions from professional nurses, asking about the perception of the influency of external factors to the organization, in relation to the employment of the Administrative Manuals.

The purpose of the present study is to analyse the Manual as an administrative way in what refers to the standardization of the nursery actions.

\section{REFERÊNCIAS BIBLIOGRÁFICAS}

1 ANDRADE, O.B. O manual de normas e procedimentos do serviço de enfermagem de saúde pública. Rev. Saúde Publ., São Paulo, 9(4): 455-66, dez. 1975.

2 BRASIL. Ministério da Saúde. Coordenadoria de Assistência Médica e Hospitalar. Normas de administração e controle do hospital. Brasília, Centro de Documentação do Ministério da Saúde, 1974.

3 CHIAVENATO, I. Introdução à teoria geral da administração. 3. ed. São Paulo, Mc Graw-Hill, 1983. $617 \mathrm{p}$.

4 LODI, J.B. História da administração. Sāo Paulo, Pioneira, 1971. 217p.

Recebido em 05/10/89 